\title{
A Mediterranean Alexandrium taylorii (Dinophyceae) Strain Produces Goniodomin A and Lytic Compounds but Not Paralytic Shellfish Toxins
}

\author{
Urban Tillmann ${ }^{1, *(\mathbb{D})}$, Bernd Krock ${ }^{1}$, Stephan Wietkamp ${ }^{1}$ and Alfred Beran ${ }^{2}$ \\ 1 Alfred Wegener Institute-Helmholtz Zentrum für Polar- und Meeresforschung, Am Handelshafen 12, \\ D-27570 Bremerhaven, Germany; bernd.krock@awi.de (B.K.); Stephan.Wietkamp@awi.de (S.W.) \\ 2 National Institute of Oceanography and Applied Geophysics-OGS, via Piccard 54, I-34151 Trieste, Italy; \\ aberan@inogs.it \\ * Correspondence: urban.tillmann@awi.de; Tel.: +49-471-4831-1470
}

Received: 30 June 2020; Accepted: 27 August 2020; Published: 1 September 2020

check for updates

\begin{abstract}
Species of the dinophyte genus Alexandrium are widely distributed and are notorious bloom formers and producers of various potent phycotoxins. The species Alexandrium taylorii is known to form recurrent and dense blooms in the Mediterranean, but its toxin production potential is poorly studied. Here we investigated toxin production potential of a Mediterranean A. taylorii clonal strain by combining state-of-the-art screening for various toxins known to be produced within Alexandrium with a sound morphological and molecular designation of the studied strain. As shown by a detailed thecal plate analysis, morphology of the A. taylorii strain AY7T from the Adriatic Sea conformed with the original species description. Moreover, newly obtained Large Subunit (LSU) and Internal Transcribed Spacers (ITS) rDNA sequences perfectly matched with the majority of other Mediterranean A. taylorii strains from the databases. Based on both ion pair chromatography coupled to post-column derivatization and fluorescence detection (LC-FLD) and liquid chromatography coupled to tandem mass spectrometry (LC-MS/MS) analysis it is shown that A. taylorii AY7T does not produce paralytic shellfish toxins (PST) above a detection limit of ca. $1 \mathrm{fg}$ cell $^{-1}$, and also lacks any traces of spirolides and gymnodimines. The strain caused cell lysis of protistan species due to poorly characterized lytic compounds, with a density of 185 cells $\mathrm{mL}^{-1}$ causing $50 \%$ cell lysis of cryptophyte bioassay target cells $\left(\mathrm{EC}_{50}\right)$. As shown here for the first time A. taylorii AY7T produced goniodomin A (GDA) at a cellular level of $11.7 \mathrm{pg}$ cell $^{-1}$. This first report of goniodomin (GD) production of A. taylorii supports the close evolutionary relationship of A. taylorii to other identified GD-producing Alexandrium species. As GD have been causatively linked to fish kills, future studies of Mediterranean A. taylorii blooms should include analysis of GD and should draw attention to potential links to fish kills or other environmental damage.
\end{abstract}

Keywords: goniodomin; Gessnerium; toxins; paralytic shellfish poisoning (PSP); spirolides; lytic compounds

Key Contribution: First full toxin analysis of a Mediterranean Alexandrium taylorii and first report of production of the phycotoxin Goniodomin A by this notorious bloom-forming species.

\section{Introduction}

Exceptional densities of marine microalgae, commonly reported as blooms, are recurrently observed in many coastal areas around the world. A number of dinophycean microalgae are producers of potent phycotoxins which, during such blooms, may have major ecological (e.g., fish kills), economic (e.g., on tourism or exploitation of marine resources) and/or sanitary impacts (e.g., human poisoning). 
Among toxigenic dinophytes, the genus Alexandrium Halim is perhaps the most intensely studied group. The taxonomic history of this typical gonyaulacoid genus is quite complex and includes numerous rearrangements of species formerly classified in Gonyaulax, Protogonyaulax, Gessnerium, Goniodoma and Pyrodinium [1,2]. Some new species have recently been described and today the genus Alexandrium comprises 34 species. The importance of the genus is mainly attributed to the devastating effects of toxigenic blooms related to human poisoning via contaminated shellfish. Species of Alexandrium may produce a large variety of toxic compounds including paralytic shellfish toxins (PST) (saxitoxin and derivatives), spiroimines (spirolides, gymnodimines), goniodomins (GD), and poorly characterized extracellular lytic compounds [3]. Among these various compounds, the neurotoxic saxitoxin and its derivatives are the most well-known and widely distributed, and blooms of PST producing species regularly have devastating effects on aquaculture industry around the world. For example, in 2016 a severe Alexandrium catenella bloom of outstanding intensity and geographical extent hit Chile with devastating effects on salmon aquaculture [4,5].

Whereas toxin production is well studied for the main PST-producing species, for example for species of the former tamarense/fundyense/catenella species complex or for A. minutum, much less is known about toxin production potential of other Alexandrium species. One of these is Alexandrium taylorii. The species was described by Balech [6] in the French Atlantic (Bay of Arcachon, France) and since then has been reported from various Mediterranean areas [7] as well as from Indonesia [8], Malaysia [9], and Japan [10]. Alexandrium taylorii is a high biomass producer species causing very dense and recurrent blooms in various parts of the Mediterranean Sea including the Catalano-Balearic, Adriatic, Tyrrhenian and Ionian Sea, where peak densities of $10^{6}-10^{7}$ cells $\mathrm{L}^{-1}$ and intense water discolorations are reported [7,11-16]. However, toxin production potential of $A$. taylorii is poorly known and there are only few and partly contradictory studies available. Mediterranean strains are usually listed and cited as non-PST-producers $[15,17,18]$, however, this belief is not based on actual data or is simply based on "pers. comm." information [19]. The same refers to a strain classified as A. taylorii from Indonesia, which was referred to as a strain that did not produce PST, but again only based on "pers.comm." and not on published data [8]. Nevertheless, for one Mediterranean strain, AY1T, methodological details confirming lack of detectable PST was published [20]. In contrast, PST production based on high performance liquid chromatography (HPLC) toxin analysis was claimed for a Malaysian strain of $A$. taylorii [9].

Moreover, $A$. taylorii has been reported to severely affect oyster larvae [8] and to produce hemolytic exotoxins [10]. It must be noted, however, that in both reports neither morphological nor sequence data is provided supporting the species identification. On the other hand, the Mediterranean strain AY1T, for which sequence data are available in GenBank, was shown to immobilize and lyse a protistan grazer which is indicative of the production of extracellular lytic compounds by A. taylorii [20].

Morphological evidence, i.e., a pentagonal first apical plate disconnected from the apical pore plate [6], indicates a close relationship of $A$. taylorii with other species of the subgenus Gessnerium as defined by Balech [21], and such a relationship is confirmed in phylogenetic trees for $A$. taylorii with A. monilatum, A. pseudogonyaulax, A. hiranoi, and A. satoanum [22,23]. Interestingly, species of this cluster are known as producers of goniodomin A (GDA) (Figure 1), a potent antifungal toxin associated with invertebrate mortality [24], which was first identified by Sharma et al. [25]. Whereas the species identity of the Alexandrium sp. source organism studied by Sharma et al. [25] cannot be determined retrospectively [26], GDA has been identified in A. hiranoi [27], A. monilatum [28], and A. pseudogonyaulax [29]. The other two species of the phylogenetic cluster, $A$. satoanum and A. taylorii, have never been tested for the presence of this toxin. 


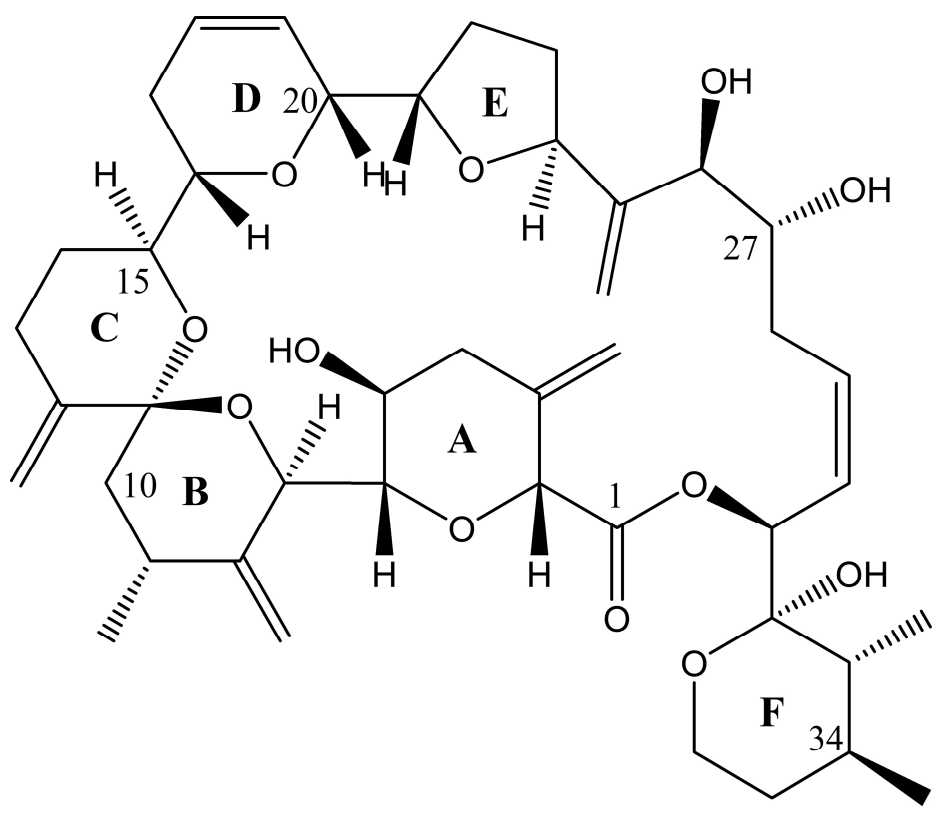

Figure 1. Chemical structure of goniodomin A.

The aim of the present study is thus to investigate the toxin production potential of a Mediterranean A. taylorii strain by combining state-of-the-art screening for various toxins known to be produced within Alexandrium with a sound morphological and molecular designation of the studied strain.

\section{Results}

\subsection{Species Identification}

Cells were slightly variable in shape from subspherical to irregularly hexagonal (Figure 2A,B) without significant dorsoventral compression. The epitheca was rounder than the trapezoidal hypotheca. Cell size ranged from 34.3 to $48.2 \mu \mathrm{m}$ in cell length (mean $40.4 \pm 3.3 \mu \mathrm{m}$ ) and 33.6 to $49.3 \mu \mathrm{m}$ in cell width (mean: $41.6 \pm 3.7 \mu \mathrm{m}$ ) with a mean length/width ratio of $0.97 \pm 0.03(n=52)$. The cingulum was narrow, excavated, without lists, and ventrally displaced by slightly more than one cingular width (Figure 2C). The cell content was brownish (Figure 2C-E) and could be quite dark and granular. There were numerous regularly distributed small chloroplasts visible in fluorescence microscopy (Figure 2K,L). Position and shape of the nucleus was difficult to resolve in unstained cells, but with DAPI staining it was seen to be elongated and located in the cingular plane (Figure $2 \mathrm{~K}-\mathrm{M}$ ) with its U-shape clearly visible in apical view (Figure 2N,O). In the culture there were two types of cell division. Cells divided in the motile stage with an oblique fission line by desmoschisis, i.e., the thecal plates were shared between the two new cells (Figure 2D,E). Additionally, cells could shed their theca (ecdysis) (Figure 2F,G) forming temporary cysts, which subsequently may undergo cell division (Figure 2H-J).

The theca was composed of thin and smooth plates which were irregularly covered by minute pores (Figure 3). Staining of thecal plates revealed the plate formula typical for Alexandrium (Po, $4^{\prime}$, $\left.6^{\prime \prime}, 6 \mathrm{c}, 8(?) \mathrm{s}, 5^{\prime \prime \prime}, 2^{\prime \prime \prime \prime}\right)$ (Figure 3$)$. The first apical plate was slightly variable in its size and shape (see Figure S1), but generally short and consistently and entirely disconnected from the apical pore plate (Po). In most cases it was pentagonal with two anterior margins, with the left side touching plate $2^{\prime}$ being shorter than the right margin touching plate $4^{\prime}$ (Figure $3 \mathrm{~A}, \mathrm{~B}$ ). However, plate $1^{\prime}$ could also be rather quadrangular with just one long apical suture and without contact to plate $2^{\prime}$ (Figure $3 \mathrm{C}$ ). A usually large ventral pore (vp) was located above plate $1^{\prime}$ at the junction of plates $1^{\prime}, 2^{\prime}$ and $4^{\prime}$ and could occasionally also be seen in light microscopy (Figure 2C). When the left anterior margin of plate $1^{\prime}$ was missing the vp was located at the confluence of plates $1^{\prime}, 2^{\prime}, 4^{\prime}$ and $1^{\prime \prime}$. The vp may touch 
the $1^{\prime}$ plate but in many cases was slightly more anterior in position on the suture of plates $2^{\prime}$ and $4^{\prime}$ (Figure 3A,B). Exceptionally, no vp could be detected or two vp were present (Figure S1). The Po had a rounded dorsal and more pointed ventral side and had a large comma shaped pore (Figure 3D,E). The three apical plates surrounding Po were comparable in size with an almost symmetrical plate $3^{\prime}$ in dorsal position (Figure 3D). Precingular plates were of comparable size (Figure 3D), but the ventrally located plate $6^{\prime \prime}$ was distinctly smaller, comparable in size to plate $1^{\prime}$, pentagonal in shape, and longer than wide (Figure $3 \mathrm{~A}-\mathrm{C}$ ). The anterior sulcal plate (sa) was located below plate $1^{\prime}$ and $6^{\prime \prime}$. It was very narrow and its left lateral suture to plate $C 1$ was not extending the left lateral suture of plate $1^{\prime}$ with plate $1^{\prime \prime}$ (Figure 3A-C,G). The posterior sulcal plate (sp) was variable in shape and appearance (Figure S2), but generally elongated, longer than wide, and with a characteristically V-shaped anterior part touching the other sulcal plates (Figure 3B,G,H). This plate most often was rather smooth (Figure 3G,H), but also could have a straight or slightly curved line or groove eventually ending with a small pore (Figure 3I). In the central sulcal area six smaller plates could clearly be identified (Figure 3G). Plate ssa was large and appeared more as a precingular than a sulcal plate and had a small list around its sutures (Figure 3A-C,F,G). The right posterior sulcal plate (sdp) was slenderer and longer than the left posterior sulcal plate (ssp) (Figure 3G). The presence of two additional very tiny accessory sulcal plates was adumbrated but could not be unambiguously demonstrated.

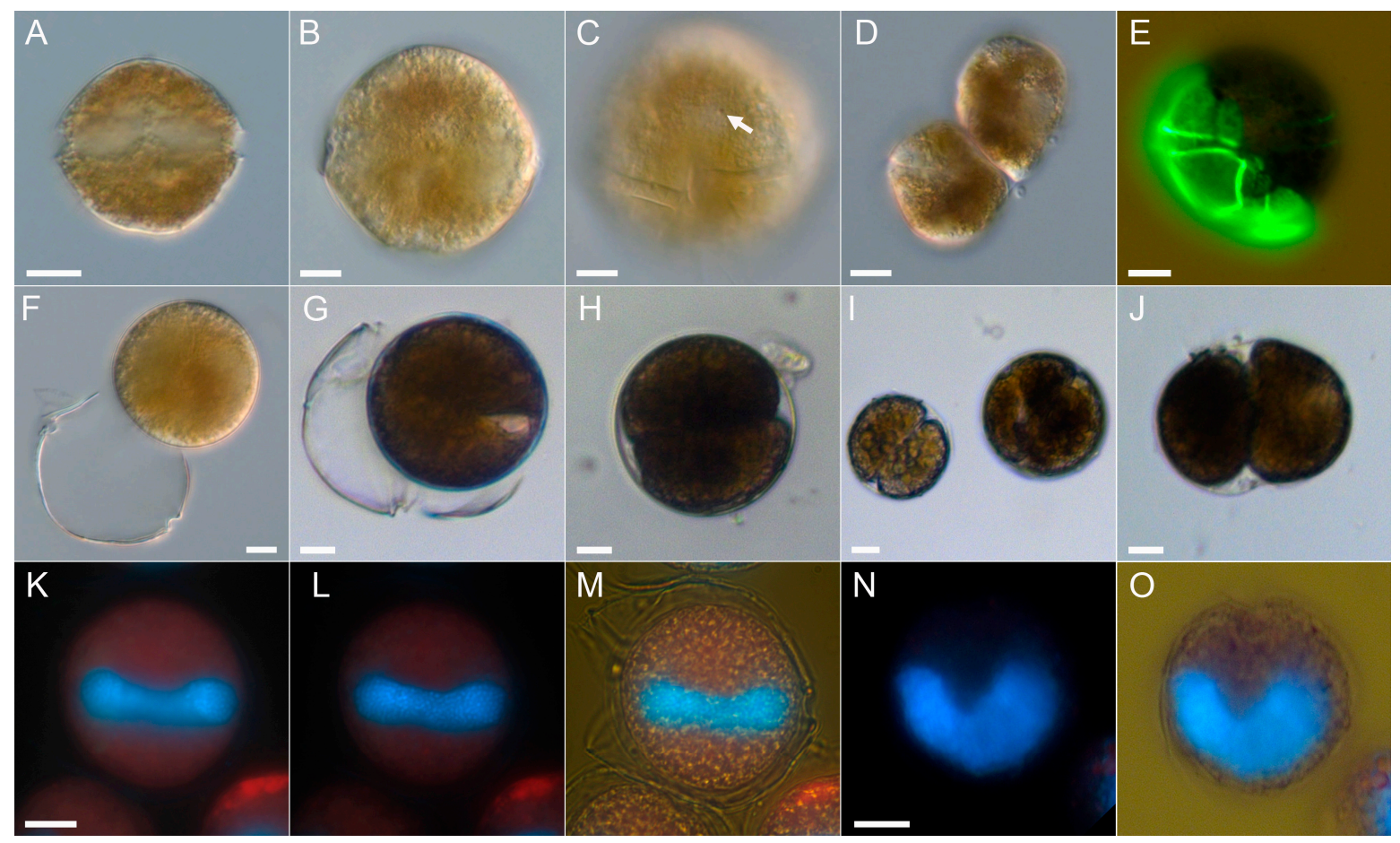

Figure 2. Alexandrium taylorii AY7T, LM micrographs of living (A-D,F-J) or fixed (E,K-O) cells. (A-C) General size and shape. Note the ventral pore (arrow) in (C). (D) Newly divided motile pair of cells. (E) Newly divided cell stained with Solophenyl Flavine showing presence of half of the parent thecal plates. (F,G) Temporary cyst formation after ecdysis of the whole theca. (H-J) Different temporary cysts with cells in division. (K-M) Different focal planes and illumination of the same cell stained with DAPI to indicate shape and position of the nucleus (blue). $(\mathbf{N}, \mathbf{O})$ Two views of the same DAPI-stained cell in apical view. Scale bars $=10 \mu \mathrm{m}$.

The newly obtained AY7T large subunit (LSU) sequence was identical with most LSU reference sequences (Table 1). Only strain AY4T differed from all others (including the new AY7T) by two nucleotides. Three identical A. taylorii LSU sequences from Japan (strains Atay99Shio, Table S1) revealed significant base pair differences compared to Mediterranean A. taylorii, e.g., 5.5\% different 
to AY7T, 8.3\% different to AY1T, or 8.1\% different to AY4T. There were no previously deposited LSU sequences of strain AY7T.

Internal Transcribed Spacers (ITS) sequence comparison of AY7T revealed 100\% identity with AY7T sequences previously deposited in Genbank and with most other ITS A. taylorii reference sequences. Among other Mediterranean strains, only strains CSIC-AV8 (La Fosca, Spain) and VGOE6 (Pagueroa, Spain) differed from other Mediterranean strains (including the new AY7T) by one nucleotide each (Table 2). However, as was the case for the LSU sequences, there were significant differences between ITS sequences of Mediterranean strains and ITS of the Japanese strain Atay99Shio-06 (AB841262.1, Table S1), with, for example, 109 bp differences compared to strain AY7T (equivalent to 18.8\%), or 107 bp differences compared to strain AT1T (equivalent to $21.6 \%$ ), respectively.
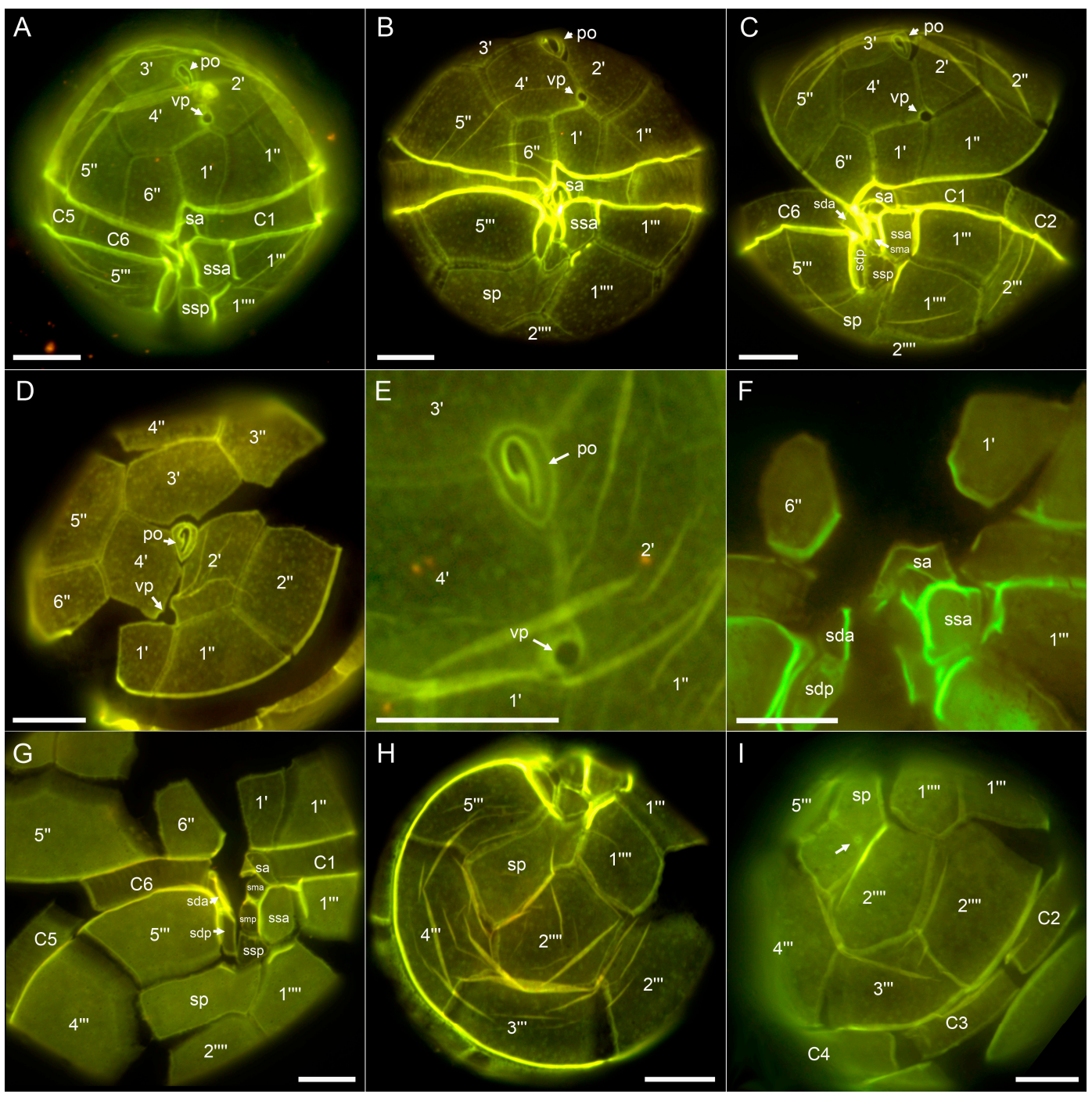

Figure 3. Alexandrium taylorii AY7T, different thecae of Lugol-fixed cells stained with Solophenyl Flavine and viewed with epifluorescence and blue light excitation. (A-C) Cells in ventral view. (D) Epithecal plates in apical view. (E) Detailed apical view of the pore plate (Po) and the ventral pore (vp). (F) Detailed view of the sulcal area to show shape of the anterior sulcal plate (sa). (G) Hypothecal and sulcal plates in ventral view. (H,I) Hypothecal plates in antapical view. Note the groove ending with a small pore (arrow in I). Plate labels according to the Kofoidian system. Sulcal plate labels: $\mathrm{sp}=$ posterior sulcal plate; sdp = right posterior sulcal plate; $\mathrm{ssp}=$ left posterior sulcal plate; $\mathrm{sda}=$ right anterior sulcal plate; $\mathrm{smp}=$ median posterior sulcal plate; sma = median anterior sulcal plate; $\mathrm{sa}=$ anterior sulcal plate. Scale bars $=10 \mu \mathrm{m}$. 
Table 1. Sequence alignment of the homologous fragment for the A. taylorii large subunit (LSU) sequences.

\begin{tabular}{ccc}
\hline Strain & Sequence $\left(5^{\prime}-\mathbf{3}^{\prime}\right)$ & Nucleotide Positions (bp) \\
\hline AY7T (this study) & CATTAATTTGGACTTGGTGCAA & $547-568$ \\
\hline AY4T & & $555-576$ \\
\hline AY1T & - AG- & $516-537$ \\
\hline AY2T & - & $551-572$ \\
\hline
\end{tabular}

Table 2. Sequence alignment of the homologous fragment for the A. taylorii Internal Transcribed Spacers (ITS) sequences. Dots represent 134 base pairs, which are identical in the ITS sequences of all strains shown in the table.

\begin{tabular}{|c|c|c|}
\hline Strain & Sequence $\left(5^{\prime}-3^{\prime}\right)$ & Nucleotide Positions (bp) \\
\hline AY7T (this study) & GATCCAA $\ldots . . . \ldots$.AGGCATC & $354-360 \ldots \ldots \ldots .494-500$ \\
\hline CSIC-AV8 & $-\mathrm{T}-\ldots \ldots \ldots \ldots$ & $314-320 \ldots \ldots . .454-460$ \\
\hline VGO704, VGOE6 & $-\ldots \ldots \ldots \ldots-\mathrm{A}-$ & $314-320 \ldots \ldots \ldots .454-460$ \\
\hline AY10T & $-\ldots \ldots \ldots \ldots$ & $314-320 \ldots \ldots \ldots .454-460$ \\
\hline AY1T & $-\ldots \ldots \ldots \ldots$ & $314-320 \ldots \ldots \ldots .454-460$ \\
\hline AY7T & $-\ldots \ldots \ldots \ldots$ & $314-320 \ldots \ldots \ldots .454-460$ \\
\hline CBA-1 & $-\ldots \ldots \ldots \ldots$ & $314-320 \ldots \ldots \ldots .454-460$ \\
\hline CNR-AT4 & $-\ldots \ldots \ldots \ldots$ & $314-320 \ldots \ldots \ldots .454-460$ \\
\hline CNR-ATAYB2 & $-\ldots \ldots \ldots \ldots$ & $314-320 \ldots \ldots \ldots .454-460$ \\
\hline Field sample & $\longrightarrow \ldots \ldots \ldots$. & $314-320 \ldots \ldots \ldots .454-460$ \\
\hline Temporary-cyst & $-\ldots \ldots \ldots \ldots$ & $314-320 \ldots \ldots .454-460$ \\
\hline VGO705 & $-\ldots \ldots \ldots \ldots$ & $314-320 \ldots \ldots \ldots .454-460$ \\
\hline
\end{tabular}

\subsection{Toxin Analysis}

\subsubsection{PST}

No PST were detected in A. taylorii AY7T by either ion pair chromatography coupled to post-column derivatization and fluorescence detection (LC-FLD) (Figure S3) or hydrophilic interaction liquid chromatography-tandem mass spectrometry (HILIC-MS/MS) (Figure S4), two independent methodological approaches. LC-FLD resulted in higher detection limits ranging for individual PST from 25 to $715 \mathrm{fg} \mathrm{cell}^{-1}$. In contrast, HILIC-MS/MS yielded orders of magnitude lower detection limit (LOD) between 0.1 and $1.9 \mathrm{fg}$ cell $^{-1}$ (Table 3). 
Table 3. Cellular detection limits (LOD) of paralytic shellfish toxins (PST) determined by ion pair chromatography coupled to post-column derivatization and fluorescence detection (LC-FLD) and hydrophilic interaction liquid chromatography-tandem mass spectrometry (HILIC-MS/MS). nd = not determined.

\begin{tabular}{|c|c|c|}
\hline Toxin & $\begin{array}{c}\text { LOD (FLD) [fg } \\
\left.\text { cell }^{-1}\right]\end{array}$ & $\begin{array}{l}\text { LOD (MS/MS) } \\
{\left[\text { ffg cell }^{-1}\right]}\end{array}$ \\
\hline $\mathrm{C} 1$ & 57 & 0.25 \\
\hline $\mathrm{C} 2$ & 57 & 0.76 \\
\hline $\mathrm{C} 3$ & nd & 0.49 \\
\hline $\mathrm{C} 4$ & nd & 1.87 \\
\hline B1 & 141 & 0.12 \\
\hline B2 & nd & 0.49 \\
\hline STX & 35 & 0.13 \\
\hline NEO & 516 & 0.63 \\
\hline GTX1 & 715 & 0.07 \\
\hline GTX2 & 26 & 0.24 \\
\hline GTX3 & 32 & 0.18 \\
\hline GTX4 & 722 & 0.16 \\
\hline dcSTX & 51 & 0.15 \\
\hline dcNEO & nd & 0.34 \\
\hline dcGTX1 & nd & 0.35 \\
\hline dcGTX2 & 25 & 0.49 \\
\hline dcGTX3 & 25 & 0.45 \\
\hline dcGTX4 & nd & 0.84 \\
\hline doSTX & nd & 0.09 \\
\hline TTX & nd & 0.18 \\
\hline
\end{tabular}

\subsubsection{Lipophilic Compounds}

In addition to PST, the $A$. taylorii AY7T strain also was analysed for other toxin groups known to be produced by species of the genus Alexandrium, namely cycloimines, such as spirolides (SPX), gymnodimines (GYM) and goniodomins (GD). No cycloimines were detected above the LOD of $0.6 \mathrm{fg}$ cell $^{-1}$ of SPX and $0.8 \mathrm{fg}$ cell $^{-1}$ of GYM based on the molecular response of 13-desmethyl SPX (SPX-1) and GYM A, respectively. Alexandrium taylorii was instead found to contain goniodomin A (GDA) (Figure 4) at a level of $11.7 \mathrm{pg}$ cell $^{-1}$. In addition, our data/analysis profiles/analytical results showed evidence of additional GD analogues that will be the subject to future research. 
A

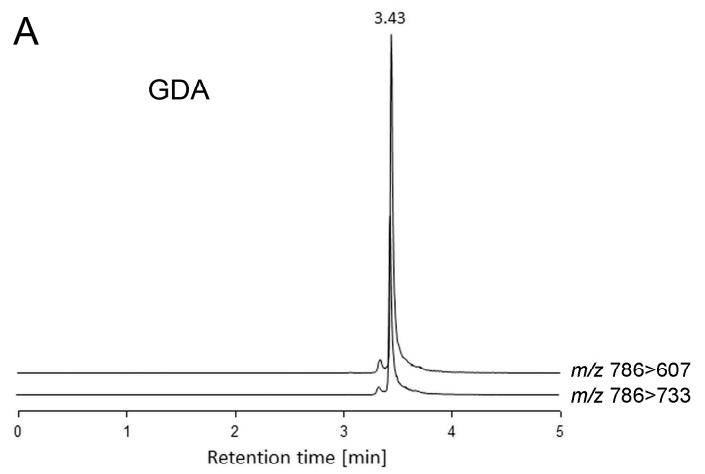

C

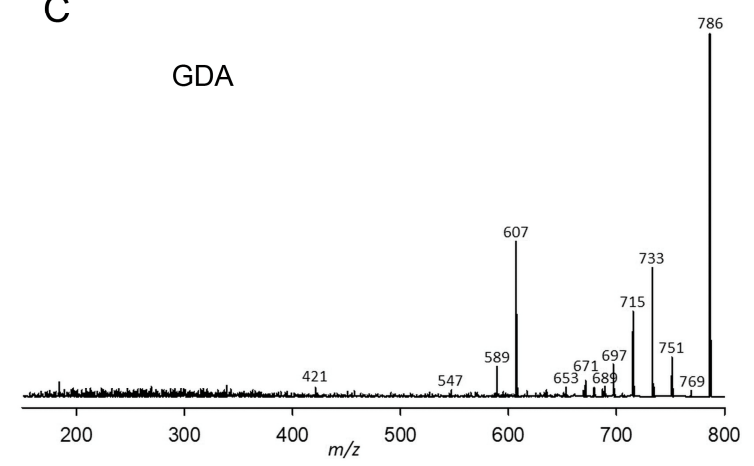

B

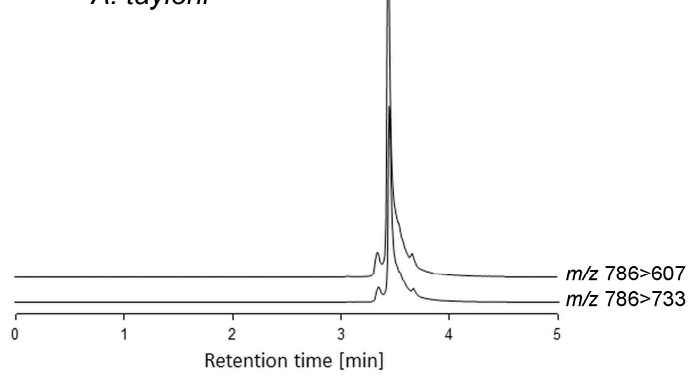

D

A. taylorii

Figure 4. LC-MS/MS chromatograms of the ion transitions $m / z 786>607$ and $786>733$ of (A) a

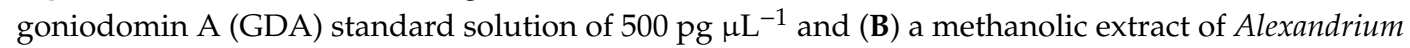
taylorii AY7T as well as collision induced dissociation (CID) spectra of (C) a GDA standard solution of $500 \mathrm{pg} \mathrm{LL}^{-1}$ and (D) a methanolic extract of Alexandrium taylorii AY7T.

\subsubsection{Lytic Capacity}

The dose response curve of Rhodomonas cell lysis exposed to different $A$. taylorii densities (Figure 5) revealed no significant effect on the target cells for the two lowest $A$. taylorii AY7T concentrations $<50$ cell $\mathrm{mL}^{-1}$. At higher $A$. taylorii densities, the number of intact Rhodomonas decreased consequently and total cell lysis was observed at the highest $A$. taylorii concentration of $1.9 \times 10^{3}$ cells $\mathrm{mL}^{-1}$. EC 50 was calculated as 185 cells $\mathrm{mL}^{-1}$ (95\% confidence interval: 176-195 cells $\left.\mathrm{mL}^{-1}\right)$.

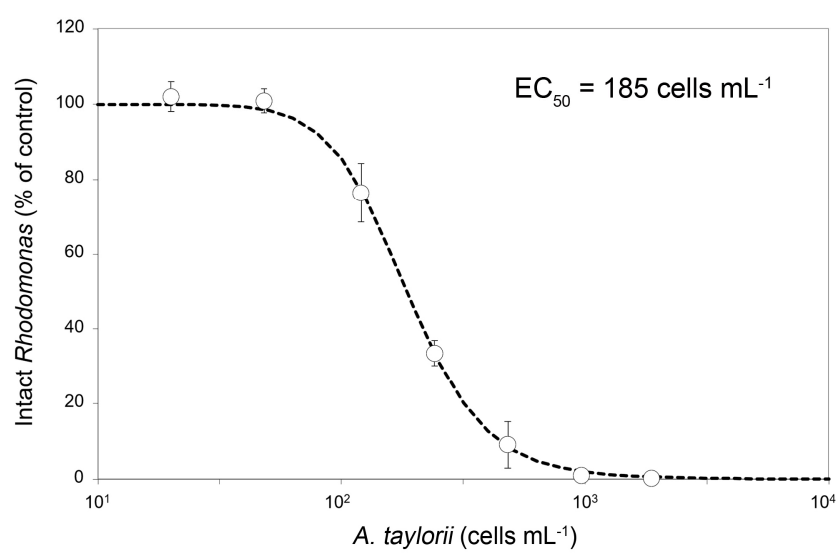

Figure 5. Cell bioassay with the cryptophyte Rhodomonas salina undergoing cell lysis when exposed to whole cells of Alexandrium taylorii AY7T. Intact target cells (\% of control) plotted against log-transformed A. taylorii density $\left(\mathrm{mL}^{-1}\right)$. Results are expressed as triplicate mean $\pm 1 \mathrm{SD}$. 


\section{Discussion}

Species-level toxinological data from the literature are only as good as the underlying taxonomical determination of the species/strains under study. It is therefore desirable to document the identification of the organism either morphologically or with molecular techniques when conducting chemical toxin analyses, as was done here. If the strain is sufficiently documented elsewhere, a strain identifier and literature citation should be provided. However, use of a previously described strain does not provide $100 \%$ certainty, as cross-contamination or even misidentification at the culture collection cannot be ruled out. The problem of reliable species identification especially refers to Alexandrium where most taxa are rather similar in general size and shape [21]. Alexandrium species identification is thus not a simple task and requires a thorough examination of subtle morphological differences in size and shape of diagnostic thecal plates such as the apical pore plate, the first apical plate, or of sulcal plates $[3,21]$. Moreover, recent phylogenetic studies revealed cryptic speciation and also invalidated some of the described morphospecies [30,31]. A prominent example of an Alexandrium morphospecies concept failure for species circumscriptions is the former $A$. tamarense species complex consisting of the morphospecies A. tamarense, A. catenella, and A. fundyense [30,32,33], where new species (i.e., A. catenella, A. mediterraneum, A. tamarense, A. pacificum, A. australiense) are now defined based on sequence data and the segregation into five genetic distinct clades [34].

Species determination of $A$. taylorii is also challenging. The description of the species [6] was based on field samples and no DNA sequences are available and linked to the type material. This ambiguity is illustrated by divergent sequences deposited in GenBank under the name A. taylorii; sequences labelled as A. taylorii based on strains isolated from Japan (Table S1) differ substantially from sequence data obtained from Mediterranean A. taylorii. No morphological data are linked to the Japanese strains. For Mediterranean A. taylorii, field populations of two Spanish coastal sites were compared morphologically with A. taylorii populations from the type locality (French Atlantic) and were found to be within the range of intraspecific morphological variability [14]. For Mediterranean strain-based sequence data, there is thus at least indirect evidence that their morphology is likely to conform to A. taylorii sensu Balech. Moreover, for five Mediterranean strains, for which ITS sequence data were deposited in GenBank, morphology was examined by staining thecal plates [7], even though description or micrograph documentation was not provided. Likewise, six strains of $A$. taylorii from the Mediterranean with identical ITS sequences were examined morphologically by thecal plate dissection, and two A. taylorii cells of unknown strain identity were depicted [18]. For Adriatic A. taylorii strains with sequence data deposited at GenBank (AY1T, AY2T AY4T, AY7T, AY10T), no detailed morphological examination is published yet, but are now available for AY7T (Figure 2; Figure 3, Figures S1 and S2).

Morphology of AY7T largely conformed with the original species description of A. taylorii [6]. Cells of AY7T were slightly larger (length range 34.3-48.2 $\mu \mathrm{m}$ ) than reported by Balech [6] (length range 31-44 $\mu \mathrm{m})$, and larger than cells of the Spanish A. taylorii field population, where cell length ranged from 27 to $43 \mu \mathrm{m}$ and from 26 to $43 \mu \mathrm{m}$ for cells from Palmira and La Fosca, respectively [14]. In the original [6] and subsequent species descriptions [21], Balech did not explicitly mention variability in shape of plate $1^{\prime}$. However, such a variability, ranging from asymmetrical pentagonal to almost quadrangular, without contact to plate $2^{\prime}$ is evident in strain AY7T and has been documented for field population from the type locality (Arcachon, French Atlantic) and also from the Spanish Mediterranean [14]. Moreover, position of the ventral pore was also variable in the before mentioned field study [14] and in strain AY7T (Figure 3A-C, Figure S1). Notably, the exceptional presence of two ventral pores (Figure S1T) was also noted by Balech [21] and Delgado et al. [14]. An exceptional lack of a ventral pore (Figure S1S) was not reported before but confirms previous notions for other Alexandrium species that presence/absence of a vp is not a stable character [35]. One feature of thecal pattern differed consistently in strain AY7T compared to Balech's original species description: the anterior sulcal plate sa. This plate is described and depicted by Balech $[6,21]$ as very long with a significant anterior contact line to plate $1^{\prime \prime}$. However, for strain AY7T, sa was narrow and its right border was almost lined up with the right suture of plate $1^{\prime}$ so that there was almost no contact of plate sa and 1" (Figure 2A-C,F, Figure S1). Such a narrow sa 
plate was also described by Delgado et al. [14] for field samples from the type locality and from the Mediterranean and is also visible for cultured specimens from other Mediterranean localities $[18,19,36]$. Length of sa plate and the relative position of its right suture is thus not a constant and reliable feature of $A$. taylorii. In cultured cells of AY7T there was also a large variability in shapes of the posterior sulcal plate. Whereas this plate was consistently longer than wide and oblique to the right, there was consistent variability in presence/absence of the oblique groove extending from the right margin to the center and the presence/absence of a small pore at its end. Balech [21] noted that such a pore occurred "frequently" but it was only occasionally visible in cells of AY7T. Despite such minor deviation from Balech's cell description, we are confident that strain AY7T corresponds to A. taylorii.

The notion that other Mediterranean A. taylorii strains do not produce PST [17-19] is now substantiated by detailed data on strain AY7T, which is solidly based on two different analytical methods and detailed estimated LOD values of about $1 \mathrm{fg}$ cell $^{-1}$. Given the fact that PST-producing Alexandrium species usually have PST cell quotas in the $\mathrm{pg} \mathrm{cell}^{-1}$ range, $A$. taylorii AY7T can be regarded as a non-PST-producing strain. However, it has to be discussed whether or not toxin production is a stable species-specific trait. Whereas for a given clonal strain toxin production is generally proposed to be a genetically fixed and stable character [3,37], both toxic and non-toxic strains of the same species may occur. For PST, recent molecular work on presence/absence of genes responsible for toxin production as well as chemical toxin analysis of multiple strains indicate that, among the new species of the former tamarense/catenella/fundyense species complex, strains of A. catenella and A. pacificum consistently produce PST, whereas strains of $A$. tamarense and A. mediterraneum do not [32]. However, whereas most strains of the fifth species of this complex, A. australiense, do not produce saxitoxins above detection limits, one PST-producing strain of this species was described [38]. Likewise, for the very well-studied A. minutum and A. ostenfeldii, both PST-producing strains and strains without PST production have been reported [31,39-41]. Conflicting reports of PST-producing and non-toxic strains within less well studied Alexandrium are also present, for example, for A. affine [42,43], A. andersonii [43,44], or A. leii $[42,45]$. Thus, the debated question as to whether PST production is a stable species attribute has no clear answer which underlines the value of the present study, adding sound data to clarify the situation for A. taylorii. Nevertheless, additional analyses of multiple A. taylorii strains from different areas are needed to finally evaluate if lack of PST production for A. taylorii is a stable species-specific trait, especially since one deviating report on PST in A. taylorii exists. For a Malaysian strain of A. taylorii Lim et al. [9] reported the presence of PST. Whereas the documented morphological examination of the strain supports the species determination, neither a strain identifier nor sequence data of the strain in question were provided. Of more importance, however, is the fact that the reported toxin amounts were fairly low $\left(<1 \mathrm{fmol} \mathrm{cell}^{-1}\right)$, and that the reported $A$. taylorii PST profile exactly matched with the PST profile of a strain of $A$. ostenfeldii which was simultaneously studied [9]. Although such a 1:1 match of PST toxin profile of two different but simultaneously analysed Alexandrium species of course cannot be excluded, it may at least provoke some skepticism and the consideration of cross-contamination as a potential source of reporting the presence of trace PST amounts for A. taylorii. In any case, additional analyses of the Malaysian strain and other strains of $A$. taylorii from the Pacific area are urgently needed for a final clarification of the PST production potential of this species.

Whereas it is often stated that spiroimines within Alexandrium are only produced by A. ostenfeldii [3,46], corresponding analyses of these compounds for other Alexandrium species are largely missing. In general, reporting negative results is unspectacular and, to be ratable, require detailed reporting of the methods and limits of detection and quantification. Nevertheless, it is important to have this information for better understanding of the chemo-taxonomical relevance of toxins within Alexandrium. It is provided here with respect to excluding spirolides and gymnodimines from the toxin repertoire of Mediterranean A. taylorii AY7T.

The present results of lytic capacity of the Mediterranean AY7T confirm that A. taylorii produce and release lytic compounds. Another strain (AY1T) isolated from the same area has been shown before to negatively affect protistan target species [20]. Other reports on the presence of bioactive 
compounds and negative effects of Pacific A. taylorii on oyster larvae [8] or on Artemia and mammalian erythrocytes [10] are present in the literature. However, both papers do not provide supporting morphological and/or molecular evidence that indeed A. taylorii had been studied. In the paper of Emura et al. [10], not even a strain designation is included so that a reliable attribution of the reported finding to A. taylorii is considerably weakened.

Whereas lack of PST and presence of lytic activity of A. taylorii thus confirms previous reports $[19,20]$, the presence of goniodomin A in A. taylorii as reported here has not been reported before. Goniodomin A production by A. taylorii might have been expected as this matches with its phylogenetic placement. In rRNA based phylogenetic trees $A$. taylorii forms a well-supported clade with A. monilatum (the type of Balech's subgenus Gessnerium), A. pseudogonyaulax, A. hiranoi and A. satoanum [22,23]. Among those, GDA has been identified in A. monilatum [28], A. pseudogonyaulax [29], and A. hiranoi [27,47], while GDA production of A. satoanum has not yet been investigated. All species of this cluster belong to the subgenus Gessnerium which is defined by species where the first apical plate $1^{\prime}$ is not connected and not linked in any way with the apical pore plate [21]. However, some of the species that morphologically are classified into Gessnerium, and for which molecular data are available, such as $A$. insuetum, A. margalefii and A. pohangense, clearly cluster outside of the core Gessnerium group $[3,48]$. Thus, Balech's morphological definition does not define a monophyletic group and new morphological unifiers for the core Gessnerium species would be needed. Anyhow, the current chemical evidence indicates that the Gessnerium core-species might chemotaxonomically be unique by presence of GDA and lack of PST, but this hypothesis will require the analysis of a higher number of Alexandrium species and strains, including A. satoanum, A. margalefii, A. insuetum and A. pohhangense, as well as yet uncultured species with a pentagonal and disconnected $1^{\prime}$ plate (A. balechii, A. foedum, A. concavum, A. camurascutulum, A. globosum) for the presence of GDA. Crude extract of the GDA producing $A$. monilatum was shown to cause hemolysis to erythrocytes from several mammalian species including humans [49], but lytic capacity of purified GDA has not yet unequivocally been shown. Future studies are needed to test if the lytic activity of AY7T (Figure 5) towards protistan targets are due to GDA or caused (or intensified) by other yet uncharacterized extracellular compounds.

Goniodomin A production by A. taylorii is of importance for the Mediterranean area where dense and recurrent blooms of this species occur [7,11-16]. For GDA producing A. monilatum, blooms have been linked to mortality of finfish and/or shellfish [50,51]. However, Mediterranean A. taylorii blooms have not yet been causatively linked to fish kills and are considered mainly to be of concern for tourism and recreational use of coastal waters and beaches $[15,16]$. Nevertheless, in 1999 a dense bloom with $27 \times 10^{6}$ cells $\mathrm{L}^{-1}$ of A. taylorii in the lagoon of Marano (Northern Adriatic Sea) was associated with high mortality of seabass (Dicentrarchus labrax) which is extensively cultivated in the area (Beran et Cabrini, unpublished data; presented at the Riunione Scientifica Annuale del Gruppo di Algologia Italiana, Ancona, 2000). Thus, future studies of Mediterranean A. taylorii blooms should include analysis of GDA and should draw attention to potential links to fish kills or other environmental damage.

\section{Materials and Methods}

\subsection{Strain Isolation and Harvest}

Strain AY7T (=CoSMi1017) of Alexandrium taylorii was isolated from a benthic sample collected in the lagoon of Marano in May 2000. The lagoon of Marano is a shallow and semi open lagoon connected to the Northern Adriatic Sea. Salinity during summer normally ranges from 29 to 36. Part of the lagoon is divided in so-called "valli di pesca", where seabass (Dicentrarchus labrax) is maintained in extensive culture. A massive bloom of $A$. taylorii identified by epifluorescence light microscopy using calcofluor [52] during July/August 1999 caused the loss of most of the stock. Standard tests for PST using HPLC in 1999 were negative and it was concluded at the time that the high fish mortality had probably been caused by occlusion of the gills, where many A. taylorii cells had been found in samples 
of dead fish. It was decided to test in 2000 if the mud would release fresh A. taylorii cells from resting cysts-in fact a second much smaller bloom developed in July 2000 without serious consequences.

For cell isolation, samples of ca $1 \mathrm{~mL}$ of mud were incubated in $50 \mathrm{~mL}$ of half strength medium B [53] (salinity 32) at $20^{\circ} \mathrm{C}$ under cool white fluorescent light $\left(80 \mu \mathrm{mol}\right.$ photons $\left.\mathrm{m}^{-2} \mathrm{~s}^{-1}\right)$ at a light: dark cycle of 12:12 h. First motile cells appeared in the sample after six days. Single cells were washed by transferring them three times into fresh medium under a dissection microscope (M10, Wild, Heerbrugg, Switzerland) using drawn micropipettes. Finally, single isolates were incubated at the same conditions into single wells of 24 well tissue culture plates (Corning, New York, NY, USA) containing $1 \mathrm{~mL}$ of medium. Growing cultures were adapted to full strength medium B. Several clonal strains were isolated but only strain AY7T was maintained and is now integrated in the Culture Collection of Sea Microorganisms (CoSMi) at the OGS-Trieste (http:/cosmi.inogs.it) as strain CoSMi1017.

For the experiment reported here, the strain was grown in a seawater K-medium [54] supplemented with selenite, prepared from $0.2 \mu \mathrm{m}$ sterile-filtered (VacuCap, Pall Life Sciences, Dreieich, Germany) North Sea seawater (salinity of 32) at $15{ }^{\circ} \mathrm{C}$, under cool-white fluorescent light at a photon flux density (PFD) of $50 \mu \mathrm{mol}$ photons $\mathrm{m}^{-2} \mathrm{~s}^{-1}$ on a $16 \mathrm{~h}$ light: $8 \mathrm{~h}$ dark photo-cycle. For DNA sampling strain AY7T was grown in $70 \mathrm{~mL}$ plastic culture flasks. Cells in exponential phase were harvested by centrifugation at $3220 \times \mathrm{g}$ for $10 \mathrm{~min}$ (Eppendorf 5810R, Hamburg, Germany) of $50 \mathrm{~mL}$ culture, and cell pellets were stored at $-20{ }^{\circ} \mathrm{C}$ until further analysis. For toxin analysis, strain AY7T was grown in $250 \mathrm{~mL}$ plastic culture flasks under standard culture conditions. Cell concentrations from cultures in early stationary phase (at cell densities ranging from 1000 to 2000 cells $\mathrm{mL}^{-1}$ ) were determined by settling Lugol's iodine-fixed samples and counting $>400$ cells under an inverted microscope. Cell pellets were harvested by centrifugation (Eppendorf 5810R, 3220× g, $10 \mathrm{~min}$ ) and one pellet containing 227,000 cells was extracted for lipophilic toxins with $500 \mu \mathrm{L}$ methanol, and another pellet containing 37,900 cells was extracted for paralytic shellfish toxins (PST) with $500 \mu \mathrm{L} 0.03 \mathrm{M}$ acetic acid, respectively. Therefore, samples were reciprocally shaken for $45 \mathrm{~s}$ at $6.5 \mathrm{~m} \mathrm{~s}^{-1}$ with $0.9 \mathrm{~g}$ lysing matrix D (Thermo Savant, Illkirch, France) in a FP120 FastPrep instrument. Extracts were then centrifuged (Eppendorf $5415 \mathrm{R}$ ) for $15 \mathrm{~min}$ at $16,100 \times \mathrm{g}$ at $4{ }^{\circ} \mathrm{C}$. Each supernatant was transferred to a $0.45 \mu \mathrm{m}$ pore-size spin-filter (Millipore Ultrafree), and centrifuged for $30 \mathrm{~s}$ at $800 \times g$, the resulting filtrate being transferred into an ultra performance liquid chromatography (UPLC) autosampler vial for UPLC-MS/MS analysis.

\subsection{Microscopy}

Observation of living or fixed cells (formaldehyde: $1 \%$ final concentration, or neutral Lugol-fixed: $1 \%$ final concentration) was carried out using a compound microscope (Axiovert 2; Zeiss, Göttingen, Germany) equipped with epifluorescence and differential interference contrast optics. Light microscopic examination of thecal plates of $A$. taylorii was performed on fixed cells (neutral Lugol) stained with Solophenyl Flavine 7GFE500, a fluorescent dye specific to cellulose [55], which were examined with epifluorescence filter set 09 (Zeiss; BP 450-490; FT 510; LP 515). Images were taken with a digital camera (Axiocam MRc5; Zeiss). Cell length and width were measured at 1000× microscopic magnification using freshly fixed cells (formaldehyde, $1 \%$ final concentration) from dense, but healthy and growing strains (based on stereomicroscopic inspection of the living material) at early exponential phase and the Axiovision software (Zeiss).

\subsection{DNA Extraction and Sequencing}

For DNA extraction, the cell pellets were rinsed with $1 \mathrm{~mL}$ pre-heated $\left(60^{\circ} \mathrm{C}\right)$ PL1 DNA lysis buffer of the NucleoSpin Plant II DNA extraction kit (Macherey \& Nagel, Düren, Germany). The lysis buffer containing the cells was subsequently transferred to a $2 \mathrm{~mL}$ cryovial prefilled with $200 \mu \mathrm{L}$ glass beads (acid-washed, 212-300 $\mu \mathrm{m}$, Sigma-Aldrich, St. Louis, MO, USA) and stored at $-20{ }^{\circ} \mathrm{C}$. DNA was extracted using the NucleoSpin Plant II kit according to the manufacturer's instructions, with an additional cell disruption step within the beat tubes. Therefore, the samples were shaken for $45 \mathrm{~s}$ and another $30 \mathrm{~s}$ at a speed of $4.0 \mathrm{~m} \mathrm{~s}^{-1}$ in a cell disrupter (FastPrep FP120, Thermo-Savant). DNA elution 
was performed according to the manufacturer's instructions, using $2 \times 30 \mu \mathrm{L}$ of the provided elution buffer, leading to a total elution volume of $60 \mu \mathrm{L}$.

The extracted DNA of A. taylorii AY7T was subjected to polymerase strain reaction (PCR), amplifying the large subunit (LSU/28S, D1-D2 region) and the Internal Transcribed Spacers (ITS1-5.8S-ITS2) of the ribosomal DNA (rDNA). The forward and reverse primers for amplification of $28 \mathrm{~S}$ rDNA were Dir-F (5'-ACC CGC TGA ATT TAA GCA TA- $\left.3^{\prime}\right)$ and Dir-2CR (5'-CCT TGG TCC GTG TTT CAA GA-3'), respectively. The primers for amplification of the ITS region were ITSa $\left(5^{\prime}\right.$-CCA AGC TTC TAG ATC GTA ACA AGG (ACT)TC CGT AGG T-3') and ITSb (5'-CCT GCA GTC GAC A(GT)A TGC TTA A(AG)T TCA GC(AG) GG-3'), respectively. Each PCR reaction contained $16.3 \mu \mathrm{L}$ of high-grade PCR $\mathrm{H}_{2} \mathrm{O}, 2.0 \mu \mathrm{L}$ of Hotmaster Taq PCR Buffer (10×) (Quantabio, Beverly, MA, USA), $0.2 \mu \mathrm{L}$ of each primer $(10 \mu \mathrm{M}), 0.2 \mu \mathrm{L}$ of $\mathrm{dNTP}(10 \mu \mathrm{M})$ (Quantabio), $0.1 \mu \mathrm{L}$ of Taq Polymerase (Quantabio) and $1 \mu \mathrm{L}$ of DNA template $\left(10 \mathrm{ng} \mathrm{L}^{-1}\right)$ to a final volume of $20 \mu \mathrm{L}$.

Cycler conditions for LSU amplification were as follows: initial denaturation at $94{ }^{\circ} \mathrm{C}$ for $2 \mathrm{~min}$, followed by 30 cycles of denaturation at $94{ }^{\circ} \mathrm{C}$ for $30 \mathrm{~s}$, annealing at $55^{\circ} \mathrm{C}$ for $30 \mathrm{~s}$ and elongation at $68^{\circ} \mathrm{C}$ for $2 \mathrm{~min}$. A final extension step at $68^{\circ} \mathrm{C}$ for $10 \mathrm{~min}$ was performed. Cycler conditions for ITS amplification were as follows: initial denaturation at $94{ }^{\circ} \mathrm{C}$ for $4 \mathrm{~min}$, followed by 10 cycles of denaturation at $94{ }^{\circ} \mathrm{C}$ for $50 \mathrm{~s}$, annealing at $58{ }^{\circ} \mathrm{C}$ for $40 \mathrm{~s}$ and elongation at $70^{\circ} \mathrm{C}$ for $1 \mathrm{~min}$, then 30 cycles of denaturation at $94^{\circ} \mathrm{C}$ for $45 \mathrm{~s}$, annealing at $50^{\circ} \mathrm{C}$ for $45 \mathrm{~s}$ and elongation at $70^{\circ} \mathrm{C}$ for $1 \mathrm{~min}$. A final extension step at $70^{\circ} \mathrm{C}$ for 5 min was performed.

The PCR amplicons were run on a $1 \%$ agarose gel at $70 \mathrm{mV}$ for $40 \mathrm{~min}$ in TE buffer to verify that the PCR amplicons were of the expected length. The PCR amplicon was purified using the NucleoSpin Gel and PCR clean-up kit (Macherey-Nagel, Düren, Germany) and sequenced directly in both directions on an ABI PRISM 3730XL (Applied Biosystems by Thermo Fisher Scientific, Waltham, MA, USA) as described in Tillmann et al. [56]. Raw sequence data were processed using the CLC Genomics Workbench 12 (Qiagen, Hilden, Germany).

Gained LSU and ITS sequences of the actual sample of $A$. taylorii AY7T were aligned and compared to published sequences of $A$. taylorii (Table S1) using the MUSCLE algorithm implemented in the software MEGA7 (version 7.0.26; [57]). ITS sequence data of strain AY7T previously (2006) deposited in GenBank (Acc no. AM296012.1) were included in the comparison.

\subsection{Toxin Analysis}

A cell pellet was extracted with $300 \mu \mathrm{L} 0.03 \mathrm{M}$ acetic acid and another with $300 \mu \mathrm{L}$ methanol for lipophilic toxins and lyzing Matrix D (Thermo Savant) in a homogenizer (MagnaLyzer, Roche Diagnostics, Mannheim, Germany) for $45 \mathrm{~s}$ at $5500 \mathrm{~m} \mathrm{~s}^{-1}$. The homogenates were centrifuged for five min at $13,200 \times g$. The supernatants were transferred to spin filters $(0.45 \mu \mathrm{m}$, UltraFree, Millipore, Eschborn, Germany) and centrifuged for $30 \mathrm{~s}$ at $5700 \times g$. The filtrates were transferred to HPLC vials and stored at $-20^{\circ} \mathrm{C}$ until analysis.

\subsubsection{Paralytic Shellfish Toxins}

PSP toxin (PST) analysis was performed by two independent methodological approaches: by ion pair chromatography coupled to post-column derivatization and fluorescence detection (LC-FLD) and hydrophilic interaction liquid chromatography coupled to tandem mass spectrometry (HILIC-MS/MS).

LC-FLD analysis was performed on a LC1100 series liquid chromatography system consisting of a G1379A degasser, a G1311A quaternary pump, a G1229A autosampler, and a G1321A fluorescence detector (Agilent Technologies, Waldbronn, Germany), equipped with a Phenomenex Luna C18 reversed-phase column ( $250 \mathrm{~mm} \times 4.6 \mathrm{~mm}$ id, $5 \mu \mathrm{m}$ pore size) (Phenomenex, Aschaffenburg, Germany) with a Phenomenex SecuriGuard precolumn. The column was coupled to a PCX 2500 post-column derivatization system (Pickering Laboratories, Mountain View, CA, USA). Eluent A contained $6 \mathrm{mM}$ octane-sulfonic acid, $6 \mathrm{mM}$ heptane-sulfonic acid, $40 \mathrm{mM}$ ammonium phosphate, adjusted to $\mathrm{pH} 6.95$ with dilute phosphoric acid, and $0.75 \%$ tetrahydrofuran. Eluent B contained $13 \mathrm{mM}$ octane-sulfonic 
acid, $50 \mathrm{mM}$ phosphoric acid, adjusted to $\mathrm{pH} 6.9$ with ammonium hydroxide, 15\% acetonitrile and $1.5 \%$ tetrahydrofuran. The flow rate was $1 \mathrm{~mL} \mathrm{~min}^{-1}$ with the following gradient: $0-5$ min isocratic $\mathrm{A}$, 15-16 min switch to B, 16-35 min isocratic B, 35-36 min switch to A, 36-45 min isocratic A. The injection volume was $20 \mu \mathrm{L}$ and the autosampler was cooled to $4{ }^{\circ} \mathrm{C}$. The eluate from the column was oxidized with $10 \mathrm{mM}$ periodic acid in $555 \mathrm{mM}$ ammonium hydroxide before entering the $50{ }^{\circ} \mathrm{C}$ reaction coil, after which it was acidified with $0.75 \mathrm{M}$ nitric acid. Both the oxidizing and acidifying reagents entered the system at a rate of $0.4 \mathrm{~mL} \mathrm{~min}^{-1}$. The toxins were detected by dual-monochromator fluorescence $\left(l_{\mathrm{ex}} 333 \mathrm{~nm} ; 1_{\mathrm{em}} 395 \mathrm{~nm}\right)$. The data were processed with Chemstation software (Agilent, Santa Clara, CA, USA) and calibrated against external standards.

HILIC-MS/MS analysis was achieved on an Acquity UPLC Glycan BEH Amide column (130 A, $150 \mathrm{~mm} \times 2.1 \mathrm{~mm}, 1.7 \mu \mathrm{m}$, Waters, Eschborn, Germany) equipped with an in-line $0.2 \mu \mathrm{m}$ Acquity filter and thermostated at $60{ }^{\circ} \mathrm{C}$ with an isocratic elution to $5 \mathrm{~min}$ with $98 \%$ eluent B followed by a linear gradient of $2.5 \mathrm{~min}$ to $50 \% \mathrm{~B}$ and $1.5 \mathrm{~min}$ isocratic elution. The flow rate was $0.4 \mathrm{~mL} \mathrm{~min}^{-1}$, and the injection volume was $2 \mu \mathrm{L}$. Mobile phase A consisted of water with $0.15 \%$ formic acid and $0.6 \%$ ammonia (25\%). Mobile phase B consisted of water/acetonitrile (3:7, v/v) with $0.1 \%$ formic acid. Mass spectrometric experiments were performed in the selected reaction monitoring (SRM) mode on a Xevo TQ-XS triple quadrupole mass spectrometer equipped with a Z-Spray source (Waters, Halethorpe, MD, USA). Instrument parameters are given in Table S2 and used mass transitions in Table 4. PSTs were quantified by external calibration with standard mix solutions of 4 concentration levels consisting of the following PSTs: STX, NEO, GTX2/3, GTX1/4, dcSTX, dcGTX2/3, B1, and C1/2. All individual standard solutions were purchased from the Certified Reference Materials Program (CRMP) of the Institute for Marine Biosciences, National Research Council (Halifax, Canada).

Table 4. Mass transitions of PST and GC toxins. +/- indicates positive or negative ionization mode.

\begin{tabular}{|c|c|c|c|c|}
\hline & Quantifier + & Qualifier + & Quantifier - & Qualifier - \\
\hline $\operatorname{doSTX}$ & $241>60$ & $241>206$ & & \\
\hline dcSTX & $257>126$ & $257>222$ & & \\
\hline dcNEO & $273>126$ & $273>225$ & & \\
\hline STX & $300>126$ & $300>204$ & & \\
\hline NEO & $316>126$ & $316>220$ & & \\
\hline TTX & $320>302$ & $320>162$ & & \\
\hline dcGTX2 & & & $351>164$ & $351>333$ \\
\hline dcGTX3 & $353>255$ & & & $351>333$ \\
\hline dcGTX1 & & & $367>274$ & $367>349$ \\
\hline dcGTX4 & $369>271$ & & & $367>349$ \\
\hline B1 & $380>300$ & & & $378>122$ \\
\hline B2 & $396>316$ & & & $394>122$ \\
\hline GTX2 & & & $394>351$ & $394>333$ \\
\hline GTX3 & & $396>298$ & $394>333$ & \\
\hline GTX1 & & & $410>367$ & $410>349$ \\
\hline GTX4 & & $412>314$ & $410>367$ & \\
\hline
\end{tabular}


Table 4. Cont.

\begin{tabular}{ccccc}
\hline & Quantifier + & Qualifier + & Quantifier - & Qualifier - \\
\hline C1 & & & $474>122$ & $474>351$ \\
\hline C2 & $396>298$ & & $490>410$ & \\
\hline C4 & $412>314$ & & $490>392$ \\
\hline GC3 & $377>359$ & $377>257$ & \\
\hline GC3a & $393>375$ & $393>257$ & \\
\hline GC6 & $393>375$ & $393>273$ & \\
\hline GC6a & $409>391$ & $409>273$ & & \\
\hline GC3b & $457>359$ & $457>377$ & & \\
\hline GC1/2 & $473>375$ & $473>455$ & \\
\hline GC6b & $473>375$ & $473>393$ & & \\
\hline GC1a/2a & $489>409$ & $489>471$ & & \\
\hline GC4/5 & $489>489$ & $489>471$ & \\
\hline GC4a/5a & $505>425$ & $505>487$ & \\
\hline GC1b/GC2b & $553>393$ & $553>473$ & \\
\hline GC4b & $569>489$ & $569>409$ & \\
\hline GC5b & $569>409$ & $569>489$ & \\
\hline
\end{tabular}

\subsubsection{Lipophilic Compounds}

LC-MS/MS analysis for lipophilic toxins was performed on a reversed phase C18 column (Purospher STAR RP-18 end-capped ( $2 \mu \mathrm{m})$ Hibar HR 50-2.1, Merck, Darmstadt, Germany) equipped with a guard column (EXP Pre-column Filter Cartridge, Merck) and thermostated at $40{ }^{\circ} \mathrm{C}$ with an isocratic elution to $5 \mathrm{~min}$ with $5 \%$ eluent B followed by a linear gradient of $2.0 \mathrm{~min}$ to $100 \% \mathrm{~B}$ and $3.0 \mathrm{~min}$ isocratic elution prior to return to initial conditions. The flow rate was $0.6 \mathrm{~mL} \mathrm{~min}^{-1}$, and the injection volume was $0.5 \mu \mathrm{L}$. Mobile phase A consisted of $500 \mathrm{~mL}$ water with $955 \mu \mathrm{L}$ formic acid and $75 \mu \mathrm{L} \mathrm{25 \%}$ ammonia. Mobile phase B consisted of $475 \mathrm{~mL}$ acetonitrile, $25 \mathrm{~mL}$ deionized water, $955 \mu \mathrm{L}$ formic acid and $75 \mu \mathrm{L} 25 \%$ ammonia. Mass spectrometric experiments were performed in the selected reaction monitoring (SRM) mode in positive polarity on a Xevo TQ-XS triple quadrupole mass spectrometer equipped with a Z-Spray source (Waters). Instrument parameters are given in Table S3 and used mass transitions in Table 5. A standard solution of $500 \mathrm{pg}^{-1} \mathrm{~L}^{-1}$ GDA [58] was used for quantification. Standard solutions of $100 \mathrm{pg} \mu \mathrm{L}^{-1}$ SPX 1 and $50 \mathrm{pg} \mu \mathrm{L}^{-1}$ GYM A (CRMP, IMB-NRC, Halifax, NS, Canada) were used for the determination of detection limits. 
Table 5. Mass transitions of monitored lipophilic toxins. + indicates positive ionization mode.

\begin{tabular}{|c|c|c|}
\hline Toxin & Quantifier + & Qualifier + \\
\hline GYM A & $508>490$ & $508>162$ \\
\hline GYM D & $510>492$ & \\
\hline 12-me-GYM A & $522>504$ & \\
\hline GYM B/C & $524>506$ & \\
\hline GYM E & $526>508$ & \\
\hline GYM (uncharacterized) & $540>522$ & \\
\hline GYM (uncharacterized) & $542>524$ & \\
\hline SPX (uncharacterized) & $592>164$ & \\
\hline SPX (uncharacterized) & $618>164$ & \\
\hline SPX H & $650>164$ & \\
\hline SPX I & $652>164$ & \\
\hline SPX (uncharacterized) & $658>164$ & \\
\hline SPX (uncharacterized) & $666>164$ & \\
\hline SPX (uncharacterized) & $666>180$ & \\
\hline SPX (uncharacterized) & $678>150$ & \\
\hline 13,19-Didesmethyl-SPX C & $678>164$ & \\
\hline SPX (uncharacterized) & $686>164$ & \\
\hline SPX A & $692>150$ & \\
\hline 13-Desme-SPX C, SPX G & $692>164$ & \\
\hline SPX (uncharacterized) & $692>180$ & \\
\hline SPX B & $694>150$ & \\
\hline $\begin{array}{l}\text { 13-Desme-SPX D, PnTx G, } \\
\text { 20-Hydroxy-13,19-didesmethyl SPX C }\end{array}$ & $694>164$ & \\
\hline 27-Hydroxy-13-desmethyl SPX C & $694>180$ & \\
\hline 20-Hydroxy-13,19-didesmethyl-SPX D & $696>164$ & \\
\hline SPX (uncharacterized) & $698>164$ & \\
\hline SPX (uncharacterized) & $704>164$ & \\
\hline SPX (uncharacterized) & $706>150$ & \\
\hline SPX C, 20-Methyl-SPX G & $706>164$ & \\
\hline SPX D & $708>164$ & \\
\hline SPX (uncharacterized) & $708>180$ & \\
\hline SPX (uncharacterized) & $710>150$ & \\
\hline SPX (uncharacterized) & $710>164$ & \\
\hline SPX (uncharacterized) & $718>164$ & \\
\hline SPX (uncharacterized) & $720>150$ & \\
\hline SPX (uncharacterized) & $720>164$ & \\
\hline SPX (uncharacterized) & $722>164$ & \\
\hline SPX (uncharacterized) & $722>180$ & \\
\hline PnTx F & $766>164$ & \\
\hline PnTx E & $784>164$ & \\
\hline GDA & $786>607$ & $786>733$ \\
\hline
\end{tabular}




\subsubsection{Lytic Compounds}

The presence of extracellular bioactive compounds with lytic capacity was investigated using a whole cell cryptophyte Rhodomonas salina 24-h-bioassay [59,60]. Rhodomonas salina (Strain KAC30) was grown with the same medium and light/temperature settings as described for $A$. taylorii. A culture of $A$. taylorii AY7T at late exponential phase $\left(1.9 \times 10^{3}\right.$ cells $\left.\mathrm{mL}^{-1}\right)$ was used to prepare triplicate glass-vials (3.9 mL each) with seven dilutions spanning from $0.02 \times 10^{3}$ to $1.9 \times 10^{3} \mathrm{cells}^{\mathrm{mL}} \mathrm{m}^{-1}$. Triplicate glass-vials with culture medium served as control. A dense $R$. salina culture was diluted with filtered culture medium to a density of $4 \times 10^{5}$ cells $\mathrm{mL}^{-1}$. Each sample including controls was spiked $(100 \mu \mathrm{L})$ with this $R$. salina culture to yield a final $R$. salina concentration of $1 \times 10^{4}$ cells $\mathrm{mL}^{-1}$ and a final assay volume of $4 \mathrm{~mL}$ Samples were incubated for $24 \mathrm{~h}$ in the dark at $15^{\circ} \mathrm{C}$. Subsequently, samples were fixed with Lugol's iodine solution ( $2 \%$ final conc.) and intact target cells were counted with an inverted microscope (Axiovert 40c, Zeiss). Percentage of intact Rhodomonas cells were calculated as $\mathrm{Rho}_{\text {final }} / \mathrm{Rho}_{\text {control }} \times 100 \%$. EC 50 was calculated using the non-linear fit procedure of Statistika (version 9.1, StatSoft, Tulsa, OK, USA) regression of a sigmoidal curve as \%intact cells $=100 /\left[1+\left(\mathrm{X} / \mathrm{EC}_{50}\right)^{\mathrm{h}}\right]$; with $\mathrm{X}=$ the log-transformed $A$. taylorii cell concentrations and $\mathrm{EC}_{50}$ and $\mathrm{h}$ as fit-parameters. $\mathrm{EC}_{50}$, i.e., the concentration of $A$. taylorii where $50 \%$ of Rhodomonas were lysed, is expressed as cells $\mathrm{mL}^{-1}$, including $95 \%$ confidence intervals.

Supplementary Materials: The following are available online at http://www.mdpi.com/2072-6651/12/9/564/s1, Table S1: Reference LSU and ITS DNA sequences for $A$. taylorii, Table S2: MS parameters of PST and GC toxin analysis, Table S3: MS/MS parameters of lipophilic toxin analysis, Figure S1: Alexandrium taylorii AY7T. Detailed ventral views of epithecal plates of different Lugol-fixed cells stained with Solophenyl Flavine and viewed with epifluorescence and blue light excitation to illustrate shape variability of plates $1^{\prime}$ and $6^{\prime \prime}$ and variability in position of the ventral pore (vp). Note that in $(S)$ no vp could be identified, whereas in $(\mathrm{T})$ two vp were present. Plate label exemplarily shown in (A). Scale bars $=10 \mu \mathrm{m}$, Figure S2: Alexandrium taylorii AY7T. Detailed ventral or antapical views of hypothecal plates of different Lugol-fixed cells stained with Solophenyl Flavine and viewed with epifluorescence and blue light excitation to illustrate shape variability of the posterior sulcal plate sp. Note the faint groove that extends from the right margin of $\mathrm{sp}$ in $\mathrm{K}-\mathrm{T}$ (arrows) which occasionally ended in a small pore (S) or continued to the left margin (T). Scale bars $=10 \mu \mathrm{m}$, Figure S3: LC-FLD chromatograms of a PST standard mix (upper panel) and the Alexandrium taylorii extract (lower panel). Concentrations of the PST standard solution

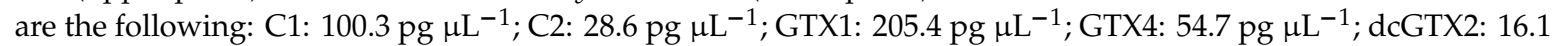
pg $\mu \mathrm{L}^{-1}$; dcGTX3: $4.5 \mathrm{pg} \mu \mathrm{L}^{-1}$; GTX2: $16.3 \mathrm{pg} \mu \mathrm{L}^{-1}$; GTX3: $5.4 \mathrm{pg} \mu \mathrm{L}^{-1}$; B1: $26.3 \mathrm{pg} \mu \mathrm{L}^{-1}$; NEO: $100 \mathrm{pg} \mu \mathrm{L}^{-1}$; dcSTX: $12.8 \mathrm{pg} \mu \mathrm{L}^{-1}$; STX: $14.7 \mathrm{pg} \mu \mathrm{L}^{-1}$, Figure S4: Extracted Ion chromatograms of a PST standard mix (upper panels) and the A. taylorii extract (lower panels).

Author Contributions: Conceptualization, U.T., B.K.; Resources, A.B.; Investigation, U.T., B.K. and S.W.; Writing-Original Draft Preparation: U.T.; Writing-Review \& Editing, U.T., B.K., S.W. and A.B.; All authors have read and agreed to the published version of the manuscript.

Funding: This work was funded by the Helmholtz-Gemeinschaft Deutscher Forschungszentren through the research programme PACES II of the Alfred Wegener Institut-Helmholtz Zentrum für Polar- und Meeresforschung.

Acknowledgments: We greatly acknowledge technical support from Annegret Müller and Thomas Max (both AWI, Bremerhaven) for cell extraction and toxin analysis, as well as from Marius Kemper (AWI, Bremerhaven) for DNA sequencing.

Conflicts of Interest: The authors declare no conflict of interest.

\section{References}

1. Taylor, F.J.R.; Fukuyo, Y. The Neurotoxigenic Dinoflagellate Genus Alexandrium Halim: General Introduction. In Physiological Ecology of Harmful Algal Blooms, 1st ed.; Anderson, D.M., Cembella, A.D., Hallegraeff, G.M., Eds.; Springer: Berlin, Germany, 1998; Volume 41, pp. 3-12.

2. Cembella, A. Alexandrium. In Harmful Algae Blooms, a Compendium Desk Reference; Shumway, S.E., Burkholder, J.A., Morton, S.L., Eds.; Wiley: Hoboken, NJ, USA, 2018; pp. 563-573.

3. Anderson, D.M.; Alpermann, T.J.; Cembella, A.D.; Collos, Y.; Masseret, E.; Montresor, M. The globally distributed genus Alexandrium: Multifaceted roles in marine ecosystems and impacts on human health. Harmful Algae 2012, 14, 10-35. [CrossRef] [PubMed] 
4. Álvarez, G.; Díaz, P.A.; Godoy, M.; Araya, M.; Ganuza, I.; Pino, R.; Álvarez, F.; Rengel, J.; Hernández, C.; Uribe, E.; et al. Paralytic shellfish toxins in surf clams Mesodesma donacium during a large bloom of Alexandrium catenella dinoflagellates associated to an intense shellfish mass mortality. Toxins 2019, 11, 18. [CrossRef]

5. Díaz, P.A.; Álvarez, G.; Varela, D.; Pérez-Santos, I.; Díaz, M.; Molinet, C.; Seguel, M.; Aguilera-Belmonte, A.; Guzmán, L.; Uribe, E.; et al. Impacts of harmful algal blooms on the aquaculture industry: Chile as a case study. Perspect. Phycol. 2019, 6, 39-50. [CrossRef]

6. Balech, E. Three new species of the genus Alexandrium (Dinoflagellata). Trans. Am. Microsc. Soc. 1994, 113, 216-220. [CrossRef]

7. Giacobbe, M.G.; Penna, A.; Gangemi, E.; Maso, M.; Garcés, E.; Fraga, S.; Bravo, I.; Azzaro, F.; Penna, A. Recurrent high-biomass blooms of Alexandrium taylorii (Dinophyceae), a HAB species expanding in the Mediterranean. Hydrobiologia 2007, 580, 125-133. [CrossRef]

8. Matsuyama, Y.; Usuki, H.; Uchida, T.; Kotani, Y. Effects of harmful algae on the early planktonic larvae of the oyster, Crassostrea gigas. In IX International Conference on Harmful Algal Blooms; Hallegraeff, G.M., Blackburn, S.I., Bolch, J.S., Lewis, R.J., Eds.; Intergovernmental Oceanographic Commission: Hobart, Australia, 2000; pp. 173-176.

9. Lim, P.T.; Usup, G.; Leaw, C.P.; Ogata, T. First report of Alexandrium taylori and Alexandrium peruvianum (Dinophyceae) in Malaysia waters. Harmful Algae 2005, 4, 391-400. [CrossRef]

10. Emura, A.; Matsuyama, Y.; Oda, T. Evidence for the production of a novel proteinaceous hemolytic exotoxin by dinoflagellate Alexandrium taylori. Harmful Algae 2004, 3, 29-37. [CrossRef]

11. Penna, A.; Giacobbe, M.G.; Penna, N.; Andreoni, F.; Magnani, M. Seasonal blooms of the HAB Dinoflagellate Alexandrium taylori Balech in a New Mediterranean Area (Vulcano, Aeolian Islands). PSZN Mar. Ecol. 2002, 23, 1-9. [CrossRef]

12. Garcés, E.; Delgado, M.; Maso, M.; Camp, J. Life history and in situ growth rates of Alexandrium taylori. J. Phycol. 1998, 34, 880-887. [CrossRef]

13. Garcés, E.; Masó, M.; Camp, J. A recurrent and localized dinoflagellate bloom in a Mediterranean beach. J. Plankton Res. 1999, 21, 2373-2391. [CrossRef]

14. Delgado, M.; Garcés, E.; Vila, M.; Camp, J. Morphological variability in three populations of the dinoflagellate Alexandrium taylori. J. Plankton Res. 1997, 19, 749-757. [CrossRef]

15. Satta, C.T.; Pulina, S.; Padedda, B.M.; Penna, A.; Sechi, N.; Luglié, A. Water discoloration events caused by the harmful dinoflagellate Alexandrium taylorii Balech in a new beach of the Western Mediterranean Sea (Platamona beach, North Sardinia). Adv. Oceanogr. Limnol. 2010, 1, 259-269. [CrossRef]

16. Basterretxea, G.; Garcés, E.; Jordi, A.; Maso, M.; Tintore, J. Breeze conditions as a favoring mechanism of Alexandrium taylori blooms at a Mediterranean beach. Estuar. Coast. Shelf Sci. 2005, 62, 1-12. [CrossRef]

17. Penna, A.; Garcés, E.; Vila, M.; Giacobbe, M.G.; Fraga, S.; Luglié, A.; Bravo, I.; Bertozzini, E.; Vernesi, C. Alexandrium catenella (Dinophyceae), a toxic ribotype expanding in the NW Mediterranean Sea. Mar. Biol. 2005, 148, 13-23. [CrossRef]

18. Penna, A.; Fraga, S.; Maso, M.; Giacobbe, M.G.; Bravo, I.; Garcés, E.; Vila, M.; Bertozzini, E.; Andreoni, F.; Luglie, A.; et al. Phylogenetic relationships among the Mediterranean Alexandrium (Dinophyceae) species based on sequences of $5.8 \mathrm{~S}$ gene and Internal Transcript Spacers of the rRNA operon. Eur. J. Phycol. 2008, 43, 163-178. [CrossRef]

19. Giacobbe, M.G.; Yang, X. The life history of Alexandrium taylori (Dinophyceae). J. Phycol. 1999, 35, 331-338. [CrossRef]

20. Tillmann, U.; John, U. Toxic effects of Alexandrium spp. on heterotrophic dinoflagellates: An allelochemical defence mechanism independent of PSP toxins. Mar. Ecol. Prog. Ser. 2002, 230, 47-58. [CrossRef]

21. Balech, E. The genus Alexandrium Halim (Dinoflagellata); Sherkin Island Marine Station Publication, Sherkin Island, Co.: Cork, Ireland, 1995; p. 151.

22. Murray, S.A.; Diwan, R.; Orr, R.J.S.; Kohli, G.S.; John, U. Gene duplication, loss and selection in the evolution of saxitoxin biosythesis in alveolates. Mol. Phylogenet. Evol. 2015, 92, 165-180. [CrossRef]

23. Tillmann, U.; Bantle, A.; Krock, B.; Elbrächter, M.; Gottschling, M. Molecular phylogenetics of the Gonyaucales based on curated rRNA sequence data and recommendations for epitypication of dinophytes exemplified with Lingulodinium polyedra. Harmful Algae 2020. in revision. 
24. Harding, J.M.; Mann, R.; Moeller, P.D.R.; Hsia, M.H. Mortality of the veined rapa whelk, Rapana venosa, in relation to a bloom of Alexandrium monilatum in the York River, United States. J. Shellfish Res. 2009, 28, 363-367. [CrossRef]

25. Sharma, G.M.; Michaels, L.; Burkholder, P.R. Goniodomin, a new antibiotic from a dinoflagellate. J. Antibiot. 1968, 21, 659-664. [CrossRef] [PubMed]

26. Harris, C.M.; Reece, K.; Stec, D.F.; Scott, G.P.; Jones, W.M.; Hobbs, P.L.M.; Harris, T.M. The toxin goniodomin, produced by Alexandrium spp., is identical to goniodomin A. Harmful Algae 2020, 92, 101707. [CrossRef]

27. Murakami, M.; Makabe, K.; Yamaguchu, K.; Konosu, S.; Wälchli, M.R. Goniodomin A, a novel polyether macrilide from the dinoflagellate Goniodoma pseudogonyaulax. Tetrahedron Lett. 1988, 29, 1149-1152. [CrossRef]

28. Hsia, M.H.; Morton, S.L.; Smith, L.L.; Beauchesne, K.R.; Muncik, K.M.; Moeller, P.D.R. Production of goniodomin A by the planktonic, chain-forming dinoflagellate Alexandrium monilatum (Howell) Balech isolated from the Gulf Coast of the United States. Harmful Algae 2006, 5, 290-299. [CrossRef]

29. Zmerli Triki, H.; Daly-Yahia, O.K.; Malouche, D.; Komiha, Y.; Deidun, A.; Brahim, M.; Laabir, M. Distribution of resting cysts of the potentially toxic dinoflagellate Alexandrium pseudogonyaulax in recently-deposited sediment within Bizerte Lagoon (Mediterranean coast, Tunisia). Mar. Pollut. Bull. 2014, 84, 172-181. [CrossRef] [PubMed]

30. Lilly, E.L.; Halanych, K.M.; Anderson, D.M. Species boundaries and global biogeography of the Alexandrium tamarense species complex. J. Phycol. 2007, 43, 1329-1338. [CrossRef]

31. Lilly, E.L.; Halanych, K.M.; Anderson, D.M. Phylogeny, biogeography, and species boundaries within the Alexandrium minutum group. Harmful Algae 2005, 4, 1004-1020. [CrossRef]

32. John, U.; Litaker, R.W.; Montresor, M.; Murray, S.; Brosnahan, M.L.; Anderson, D.M. Formal revision of the Alexandrium tamarense species complex (Dinophyceae) taxonmomy: The introduction of five species with emphasis on molecular-based (rDNA) classification. Protist 2014, 165, 779-804. [CrossRef]

33. Wang, L.; Zhuang, Y.; Zhang, H.; Lin, X.; Lin, S. DNA barcoding species in Alexandrium tamarense complex using ITS and proposing designation of five species. Harmful Algae 2014, 31, 100-113. [CrossRef]

34. Litaker, R.W.; Fraga, S.; Montresor, M.; Brosnahan, M.L.; Hoppenrath, M.; Murray, S.; Wolny, J.; John, U.; Sampedro, N.; Larsen, J.; et al. A practical guide to new nomenclature for species within the "Alexandrium tamarense species complex". Harmful Algae News 2018, 61, 13-15.

35. Hansen, G.; Daugbjerg, N.; Franco, J.M. Morphology, toxin composition and LSU rDNA phylogeny of Alexandrium minutum (Dinophyceae) from Denmark, with some morphological observations on other European strains. Harmful Algae 2003, 2, 317-335. [CrossRef]

36. Bravo, I.; Garcés, E.; Diogéne, J.; Fraga, S.; Sampedro, N.; Figueroa, R. Resting cysts of the toxigenic dinoflagellate genus Alexandrium in recent sediments from the Western Mediterranean coast, including the first description of cysts of A. kutnerae and A. perivianum. Eur. J. Phycol. 2006, 41, 293-302. [CrossRef]

37. Boczar, B.A.; Beitler, M.K.; Liston, J.; Sullivan, J.J.; Cattolico, R.A. Paralytic shellfish toxins in Protogonyaulax tamarensis and Protogonyaulax catenella in axenic culture. Plant Physiol. 1988, 88, 1285-1290. [CrossRef] [PubMed]

38. Murray, S.A.; Wiese, M.; Neilan, B.; Orr, R.J.S.; de Salas, M.; Brett, S.; Hallegraeff, G. A reinvestigation of saxitoxin production and sxtA in the "non-toxic" Alexandrium tamarense group V clade. Hamful Algae 2012, 18, 96-104. [CrossRef]

39. Kremp, A.; Tahvanainen, P.; Litaker, W.; Krock, B.; Suikkanen, S.; Leaw, C.P.; Tomas, C. Phylogenetic relationships, morphological variation, and toxin pattern in the Alexandrium ostenfeldii (Dinopyhceae) complex: Implications for species boundaries and identities. J. Phycol. 2014, 50, 81-100. [CrossRef]

40. Suikkanen, S.; Kremp, A.; Hautala, H.; Krock, B. Paralytic shellfish toxins or spirolides? The role of environmental and genetic factors in toxin production of the Alexandrium ostenfeldii complex. Harmful Algae 2013, 26, 52-59. [CrossRef]

41. Touzet, N.; Franco, J.M.; Raine, R. Characterization of nontoxic and toxin-producing strains of Alexandrium minutum (Dinophyceae) in Irish coastal waters. Appl. Environ. Microbiol. 2007, 73, 3333-3342. [CrossRef]

42. Nguyen-Ngoc, L. An autoecological study of the potentially toxic dinoflagellate Alexandrium affine isolated from Vietnamese waters. Harmful Algae 2004, 3, 117-129. [CrossRef]

43. Orr, R.J.S.; Stuken, A.; Rundberget, T.; Eikrem, W.; Jakobsen, K.S. Improved phylogenetic resolution of toxic and non-toxic Alexandrium strains using a concatenated rDNA approach. Hamful Algae 2011, 10, 676-688. [CrossRef] 
44. Ciminiello, P.; Fatturoso, E.; Forino, M.; Montresor, M. Saxitoxin and neosaxitoxin as toxic principles of Alexandrium andersoni (Dinophyceae) from the Gulf of Naples, Italy. Toxicon 2000, 38, 1871-1877. [CrossRef]

45. Usup, G.; Leaw, C.P.; Ahmad, A.; Lim, P.T. Alexandrium (Dinophyceae) species in Malaysian waters. Harmful Algae 2002, 1, 265-275. [CrossRef]

46. Mertens, K.; Adachi, M.; Anderson, D.M.; Band-Schmidt, C.; Bravo, I.; Brosnahan, M.L.; Bolach, C.J.; Calado, A.; Carbonell-Moore, M.C.; Chomérat, N.; et al. Morphological and phylogenetic data do not support the split of Alexandrium into four genera. Harmful Algae 2020. in revision.

47. Kita, T.; Fukuyo, Y. Description of the gonyaulacoid dinoflagellate Alexandrium hiranoi sp. nov. inhabiting tidepools on Japanese Pacific coast. Bull. Plankton Soc. Jpn. 1988, 35, 1-7.

48. Lim, A.S.; Jeong, H.J.; Lee, S.Y. Description of the new phototrophic dinoflagellate Alexandrium pohangense sp. nov. from Korean coastal waters. Harmful Algae 2015, 46, 49-61. [CrossRef]

49. Clemons, G.P.; Pinion, J.P.; Bass, E.; Pham, D.V.; Sharif, M.; Wutoh, J.G. A hemolytic principle associated with the red-tide dinoflagellate Gonyaulax monilata. Toxicon 1980, 18, 323-326. [CrossRef]

50. Gates, J.A.; Wilson, W.B. The toxicity of Gonyaulax monilata Howell to Mugil Cephalus. Limnol. Oceanogr. 1960, 5, 171-174. [CrossRef]

51. May, S.P.; Burkholder, J.M.; Shumway, S.E.; Hégaret, H.; Wikfors, G.H. Effects of the toxic dinoflagellate Alexandrium monilatum on survival, grazing and behavioral response of three ecologically important bivalve molluscs. Harmful Algae 2010, 9, 281-293. [CrossRef]

52. Fritz, L.; Triemer, R.E. A rapid simple technique utilizing Calcofluor White M2R for the visualization of dinoflagellate thecal plates. J. Phycol. 2004, 21, 662-664. [CrossRef]

53. Agatha, S.; Strüder-Kypke, M.C.; Beran, A. Morphological and genetic variability in the marine planktonic ciliate Laboea strobila Lohmann, 1908 (Ciliophora, Oligotrichia), with notes on its ontogenesis. J. Eukaryot. Microbiol. 2004, 51, 267-281. [CrossRef]

54. Keller, M.D.; Selvin, R.C.; Claus, W.; Guillard, R.R.L. Media for the culture of oceanic ultraphytoplankton. J. Phycol. 1987, 23, 633-638. [CrossRef]

55. Chomérat, N.; Gatti, C.M.I.; Nézan, E.; Chinain, M. Studies on the benthic genus Sinophysis (Dinophysales, Dinophyceae) II. S. canaliculata from Rapa Island (French Polynesia). Phycologia 2017, 56, 193-203.

56. Tillmann, U.; Trefault, N.; Krock, B.; Parada-Pozo, G.; De la Iglesia, R.; Vásquez, M. Identification of Azadinium poporum (Dinophyceae) in the Southeast Pacific: Morphology, molecular phylogeny, and azaspiracid profile characterization. J. Plankton Res. 2017, 39, 350-367.

57. Kumar, S.; Stecher, G.; Tamura, K. MEGA7: Molecular Evolutionary Genetics Analysis Version 7.0 for Bigger Datasets. Mol. Biol. Evol. 2016, 33, 1870-1874. [CrossRef] [PubMed]

58. Krock, B.; Tillmann, U.; Wen, Y.; Hansen, P.J.; Larsen, T.O.; Andersen, A.J.C. Development of a LC-MS/MS method for the quantification of goniodomins $\mathrm{A}$ and $\mathrm{B}$ and its application to Alexandrium pseudogonyaulax strains and plankton field samples of Danish coastal waters. Toxicon 2018, 155, 51-60. [CrossRef] [PubMed]

59. Tillmann, U.; Alpermann, T.; da Purificação, R.C.; Krock, B.; Cembella, A. Intra-population clonal variability in allelochemical potency of the toxigenic dinoflagellate Alexandrium tamarense. Harmful Algae 2009, 8, 759-769. [CrossRef]

60. Ma, H.; Krock, B.; Tillmann, U.; Cembella, A. Preliminary characterization of extracellular allelochemicals of the toxic marine dinoflagellate Alexandrium tamarense using a Rhodomonas salina bioassay. Mar. Drugs 2009, 7, 497-522. [CrossRef]

(C) 2020 by the authors. Licensee MDPI, Basel, Switzerland. This article is an open access article distributed under the terms and conditions of the Creative Commons Attribution (CC BY) license (http://creativecommons.org/licenses/by/4.0/). 